2010

\title{
They Keep It All Hid: The Ghettoization of Mental Disability Law and Its Implications for Legal Education
}

Michael L. Perlin

New YorkLaw School, michael.perlin@nyls.edu

Follow this and additional works at: https://digitalcommons.nyls.edu/fac_articles_chapters

Part of the Law and Psychology Commons, and the Legal Education Commons

\section{Recommended Citation}

Perlin, Michael L., "They Keep It All Hid: The Ghettoization of Mental Disability Law and Its Implications for Legal Education" (2010). Articles \& Chapters. 1089.

https://digitalcommons.nyls.edu/fac_articles_chapters/1089 


\title{
"THEY KEEP IT ALL HID": THE GHETTOIZATION OF MENTAL DISABILITY LAW AND ITS IMPLICATIONS FOR LEGAL EDUCATION
}

\author{
MICHAEL L. PERLIN*
}

\section{INTRODUCTION}

Here's an easy assignment: open a casebook for a course in Constitutional Law. Then, open one for a course in Civil Rights Law. Next, open one for a course in Federal Courts.

Go through the Tables of Contents. Scan the main cases to see what the topics are. Now, answer this question: what is mental disability law and how, if at all, does it relate to any of these courses?

The Supreme Court has, since 1972, decided well over fifty cases involving persons with mental disabilities, a docket spanning virtually every aspect of constitutional law and criminal procedure. ${ }^{1}$ These cases have dealt with the substantive and procedural limitations on commitment power, the conditions of confinement in psychiatric institutions, the application of the Americans with Disabilities Act to persons institutionalized because of mental illness, the substantive and procedural aspects of the criminal incompetency inquiry and the insanity defense, the relationship between mental disability and sexually violent predator laws, and all aspects of the death penalty. ${ }^{2}$

* Professor of Law and Director, Mental Disability Law Program, New York Law School; Director, International Mental Disability Law Reform Project, Justice Action Center.

1. See Michael L. Perlin, "Half-Wracked Prejudice Leaped Forth": Sanism, Pretextuality, and Why and How Mental Disability Law Developed as It Did, 10 J. CONTEMP. LEGAL ISSUES 3, 12 (1999) ("Like the moth to the flame, the U.S. Supreme Court became fascinated-perhaps preoccupied - with the full range of questions involving this population . ...").

2. See, e.g., Indiana v. Edwards, 554 U.S. _, 128 S.Ct. 2379, 2388 (2008) (finding that states can insist upon representation by counsel for those competent enough to stand trial but who suffer from severe mental illness to the point where they are not competent to conduct trial proceedings by themselves); Panetti v. Quarterman, 551 U.S. 930, 957-58 (2007) (applying the Eighth Amendment prohibition against carrying out sentence of death upon prisoner whose mental illness "obstruct[ed] a rational understanding of the State's reason for his execution"); Clark v. Arizona, 548 U.S. 735, 742 (2006) (holding that the state's insanity test stated solely in terms of capacity to tell whether an act is right or wrong does not violate due process); Atkins v. Virginia, 536 U.S. 304, 321 (2002) (finding that the execution of defendants with mental retardation violates the Eighth Amendment); Sell v. United States, 539 U.S. 166, 179 (2003) (holding that a defendant has qualified right to refuse to take antipsychotic drugs prescribed 
Thousands of cases have been decided in every state in the nation dealing with similar issues. ${ }^{3}$ In fact, in the Supreme Court's first modern mental disability

solely to render him competent to stand trial; medication over objection is permissible where court finds treatment medically appropriate, substantially unlikely to have side effects that may undermine the fairness of the trial, and, taking account of less intrusive alternatives, necessary significantly to further important governmental trial-related interests); Olmstead v. L.C., 527 U.S. 581,607 (1999) (finding that under Title II of the ADA, states are required to provide persons with mental disabilities community-based treatment when such resources are available); Kansas v. Hendricks, 521 U.S. 346, 369 (1997) (holding that a Sexually Violent Predator Act is constitutional even though additional confinement follows prison time); Godinez v. Moran, 509 U.S. 389, 399 (1993) (finding that the standard for competence to waive of counsel or entry enter a guilty plea is identical to that of competence to stand trial); Heller v. Doe, 509 U.S. 312, 314-15 (1993) (holding that statute requiring a lesser standard of proof for committal of persons with mental retardation than for persons with mental illness is constitutional); Riggins v. Nevada, 504 U.S. 127, 129 (1992) (reversing conviction because trial court enforced administration of antipsychotic drugs during defendant's trial at which he relied on the insanity defense); Zinermon v. Burch, 494 U.S. 113, $133 \mathrm{n} .18$ (1990) (holding that the state is required to inquire into person's health with a mental illness request for voluntary admission to and treatment in a mental hospital); Washington v. Harper, 494 U.S. 210, 236 (1990) (holding that the right to be free of medication must be balanced against the state's duty to treat inmates with mental illness and run a safe prison); City of Cleburne v. Cleburne Living Ctr., 473 U.S. 432, 446 (1985) (holding that mental retardation is neither a suspect class nor a quasisuspect class for equal protections purposes, but declaring exclusionary town ordinance unconstitutional); Jones v. United States, 463 U.S. 354, 369 (1983) (holding, in case challenging the terms of a post-insanity acquittal commitment, that there is no correlation between severity of crime committed and time necessary for recovery); Youngberg v. Romeo, 457 U.S. 307, 324 (1982) (holding that the state is under duty to provide institutionalized individual with safe conditions, freedom from bodily restraint, and habilitation); Mills v. Rogers, 457 U.S. 291, 303 (1982) (noting that the state may recognize, under its own constitution and common law, greater liberty interests for persons with mental illness than the U.S. Constitution in challenge to forced medication); Vitek v. Jones, 445 U.S. 480,494 (1980) (finding that an inmate is entitled to due process before he is found to be mentally ill and transferred to a mental hospital); Parham v. J.R., 442 U.S. 584, 606-08 (1979) (holding that a statute requiring a neutral fact finder to determine admission of children to state mental health hospitals in a post-admission context comports with due process); Addington v. Texas, 441 U.S. 418, 431-32 (1979) (holding that mental illness and dangerousness must be proven by more than "clear and convincing evidence" in civil commitment hearings); O'Connor v. Donaldson, 422 U.S. 563, 576 (1975) (holding it unconstitutional to confine a nondangerous person capable of surviving safely in freedom to a mental hospital); Jackson v. Indiana, 406 U.S. 715,730 (1972) (finding unconstitutional a statute that effectively condemned defendant to permanent institutionalization and deprived him of equal protection and due process under Fourteenth Amendment; the nature and duration of commitment must bear some reasonable relation to the purpose for which the individual is committed).

3. See, e.g., Rennie v. Klein, 653 F.2d 836, 843 (3d Cir. 1981) (holding that patients with mental illness committed involuntarily retain a qualified constitutional right to refuse antipsychotic drugs); Rogers v. Okin, 634 F.2d 650, 656 (1st Cir. 1980) (same); State v. Krol, 344 A.2d 289, 300-05 (N.J. 1975) (expanding procedural due process protection rights at the postinsanity acquittal commitment hearing); Wyatt v. Stickney, 325 F. Supp. 781, 785-86 (M.D. Ala. 1971), aff'd sub nom. Wyatt v. Aderholt, 503 F.2d 1305, 1316 (5th Cir. 1974) (holding that 
law case-finding that the Due Process Clause is implicated in all decisions related to both the "nature and duration" of the commitment process ${ }^{4}$ expressed surprise that there were not more mental disability law cases brought to its attention. ${ }^{5}$

So, one might think that casebooks in these topics would be laden, chockfull of mental disability law cases. This assumption, of course, is wrong. Dead wrong. One can read these casebooks cover to cover and have only the slightest and vaguest idea that "mental disability law" is a subject of any sort. Does this make sense? Is this a result of a conscious cabal? Is it inadvertent? Is it something else?

We know that this policy and practice of exclusion is not unique. Over a decade ago, Toni Massaro pointed out that constitutional criminal procedure has been treated as a subject "separate from basic constitutional law materials and courses." J. M. Balkin and Sanford Levinson offer an explanation of how this happened and why it is important.

... [E]specially after the 1960 s, constitutional law casebooks started to carve off the criminal procedure materials for reasons of space. At present only [one] casebook... retains a substantial amount of these materials,

persons with mental illness have a constitutional right to adequate treatment in mental hospitals); Lessard v. Schmidt, 349 F. Supp. 1078, 1103 (E.D. Wis. 1972) (finding that a statute that fails to provide person alleged to be mentally ill with adequate procedural safeguards is unconstitutional); Rivers v. Katz, 495 N.E.2d 337, 344 (N.Y. 1986) (holding that persons with mental illness have right to control their own medical treatment). See MiCHAEL L. PERLIN, MENTAL DisAbility Law: Civil and Criminal (2d ed. 1998-2002); Michael L. Perlin \& Heather E. Cucolo, MENTAL DisABILITY LAW: Civil AND CRIMINAL (Supp. 2009).

4. Jackson, 406 U.S. at 738.

5. See id. at 737 (footnotes omitted) ("Considering the number of persons affected, it is perhaps remarkable that the substantive constitutional limitations on this power have not been more frequently litigated.").

6. By way of example, I looked at five frequently assigned casebooks-three for constitutional law, one for civil rights law, and one for federal courts law. Two of the constitutional law casebooks included one mental disability law case (City of Cleburne) as a main case. See ERWIN CHEMERINSKy, CONSTITUTIONAL LAW 744 (3d ed. 2009); KATHLEEN SULLIVAN \& GERALD GUNTHER, CONSTITUTIONAL LAW 609 (17th ed. 2007). The civil rights casebook and the federal courts casebook included one other case (Zinermon). See JOHN JEFFRIES, JR. ET AL., CIVIL RIGHTS ACTIONS: ENFORCING THE CONSTITUTION 305 (2d ed. 2007); PETER LOW \& JOHN JeFFrIES, JR., FEDERAL COURTS AND THE LAW OF FedERAL-STATE RELATIONS 1294 (6th ed. 2008). The fifth casebook included no mental disability law case as a main case. See GEOFFREY R. STONE ET AL., CONSTITUTIONAL LAW (6th ed. 2009). The Chemerinsky book mentions Heller and Parham in notes; see CHEMERINSKY, supra, at 940, 971. The Jeffries book and the Sullivan \& Gunther book mention Youngberg in a note; see JEFFRIES, supra, at 281; SULLIVAN \& GUNTHER, supra, at 469. The Stone book mentions Parham and Vitek in notes; see STONE ET AL., supra, at 909, 949-50.

7. Toni M. Massaro, Reviving Hugo Black? The Court's "Jot for Jot" Account of Substantive Due Process, 73 N.Y.U. L. REV. 1086, 1092 n.20 (1998). 
largely, we suspect, because [one of the editors is] a noted expert on criminal procedure .... Criminal procedure, in short, has unfortunately become a specialty that is no longer taught by most ostensible "experts" on constitutional law (including ourselves)....

$\cdots$

... [I]f constitutional theorists do not pay attention to criminal procedure issues, these issues will tend to be thought of as administration of justice issues rather than questions of constitutional interpretation. The criminal procedure amendments will, in short, be written out of the legal imagination of an entire generation of constitutional scholars. ${ }^{8}$

Mental disability law-make no mistake about it—has been "ghettoized" in the same way that criminal procedure has been ghettoized. It is a ghettoization that, in some ways, is far more troubling than the criminal procedure ghettoization, since every law school in the nation (perhaps with one or two exceptions) offers at least two courses in basic criminal procedure (frequently called "Investigation" and "Adjudication"), and these courses are regularly well-subscribed, in large part since they are perceived as "bar courses." On the other hand, there are courses in "mental disability law" offered only at about half of all American law schools, and, at many schools, those courses are offered infrequently and only by adjuncts (who often have no legal training). ${ }^{9}$

I contend that the ghettoization reflects a hard truth that has passed under the radar of most civil rights teachers and civil rights students. Mental disability law is simply not a topic taken seriously as a civil rights topic (or as a constitutional law topic or as a federal courts topic). And this failure of inclusion goes directly to the heart of the challenge of teaching mental disability law. It is hidden (nearly totally hidden) from the traditional law school curriculum. It is not even in the curriculum at many law schools. It is largely invisible to students and professors alike.

I do not think this invisibility is necessarily conscious, but it is a reflection of the invidious sanism that permeates the legal academy in the same way it permeates the rest of society. ${ }^{10}$ Sanism, as I define it, is an irrational prejudice

8. J. M. Balkin \& Sanford Levinson, The Canons of Constitutional Law, 111 HARV. L. REV. 963, 1012-13 (1998).

9. A survey done by New York Law School six years ago (in anticipation of the creation of a Masters degree program in mental disability law studies, see www.nyls.edu/mdl) revealed that seventy-five ABA accredited law schools offered no course in mental disability law, no matter how characterized. Many of the other schools offered only one course sporadically (without any involvement of a full-time faculty member). Survey on file with author.

10. See, e.g., Michael L. Perlin, "His Brain Has Been Mismanaged with Great Skill": How Will Jurors Respond to Neuroimaging Testimony in Insanity Defense Cases?, 42 AKRON L. REV. 885,910 (2009) ("[Sanism] permeates all aspects of mental disability law and affects all 
of the same quality and character of other irrational prejudices that cause (and are reflected in) prevailing social attitudes of racism, sexism, homophobia, and ethnic bigotry. ${ }^{11}$ Law teachers are not immune. ${ }^{12}$ Left-leaning law teachers are not immune. ${ }^{13}$ Clinical teachers are not immune. ${ }^{14}$ Of course, lawyers who represent persons with mental disabilities are not immune. ${ }^{15}$ Eighteen years ago, in my first article-length treatment of this issue, I wrote the following passage, which I believe still rings true today:

Tenure-track professors know that articles about mental disability law topics do not augur a fast path to tenure. Most law reviews are mildly interested in, but far from eager to solicit and publish, mental disability law scholarship. In short, the study and teaching of mental disability law are marginalized in the same way that mentally disabled individuals are marginalized. The news here is not that the academy is sanist (for why should professors be immune from the pernicious impact of bias and stereotypes), but that, with some major and important exceptions, very little attention is being paid to mental disability law. $^{16}$

In this essay, I will reconsider this observation from four overlapping vantage points. First, I will consider how "mental disability law" became a part of the law school curriculum, growing out of and largely supplanting courses in "psychiatry and the law" (and why this title change is not just a question of phraseology). Second, I will discuss the significance of the notion that "mental disability law" can be cabined in a two- or three-credit course (implying that "all" mental disability law can be surveyed in that period of time, in a way that law school faculty would never think "all" tax law or real

participants in the mental disability law system: litigants, fact finders, counsel, expert and lay witnesses.").

11. See generally Michael L. Perlin, On "Sanism," 46 SMU L. ReV. 373, 374-75 (1992).

12. Michael L. Perlin, "You Have Discussed Lepers and Crooks": Sanism in Clinical Teaching, 9 CLINICAL L. REV. 683, 713-15 (2003) (discussing response of faculty colleagues to my presentation on why persons institutionalized because of mental disability should have a right to voluntary sexual interaction).

13. Id. at 713 (discussing responses to my presentation on sanism at an annual conference of the Society of American Law Teachers (SALT), a group that draws from the ranks of politically progressive law professors, including many who articulate a commitment to social justice as one of the reasons they joined the academy).

14. Id. at 720 ("[C]linical educators have-at least in the literature-been largely blind to the corrosive and ravaging forces of sanism.").

15. Michael L. Perlin, "And My Best Friend, My Doctor/Won't Even Say What It is I've Got": The Role and Significance of Counsel in Right to Refuse Treatment Cases, 42 SAN DIEGO L. REV. 735, 742 (2005); See also, Michael L Perlin, "Baby, Look Inside Your Mirror": The Legal Profession's Willful and Sanist Blindness to Lawyers with Mental Disabilities, 69 U. PITT. L. REV. 589, 604 (2008).

16. Perlin, supra note 11, at 406 (citing Thomas L. Hafemeister, Comparing Law Reviews For Their Amenability to Articles Addressing Mental Health Issues: How to Disseminate LawRelated Social Science Research, 16 LAW \& HUM. BEHAV. 219 (1992)). 
estate law or securities law could be so taught), and the significance of the reality that so many schools offer no course or only one course sporadically (often, without any involvement of a full-time faculty member). Third, I will examine the Online Mental Disability Law program at New York Law School (where I teach) from four different perspectives: (a) the pedagogy; (b) the range of subject matters taught; (c) the interdisciplinarity of the students and the faculty; and (d) the internationality of the students and intersectionality of our course offerings. Finally, and most importantly, I will return to what I partially discussed in the beginning of this introductory section, and explain why it is absolutely essential for any mental disability law course (or sequence of courses) to consider the concepts of sanism and pretextuality, the significance of "ordinary common sense" (OCS) and heuristic reasoning, and the impact of therapeutic jurisprudence.

My title is, in part, a lyric from Bob Dylan's brilliant and paradigmshattering 1965 song, Subterranean Homesick Blues, a song (unfortunately) best known for the lyric "You don't need a weatherman / to know which way the wind blows." 17 In it, Dylan rails about the government, prosecutors, society's leaders and more, in what has been called "the ultimate antiauthoritarian rap." 18 He cautions, in the lines prior to the quoted one: "Don't steal, don't lift / Twenty year of schoolin' / And they put you on the day shift," and then sings "Look out kid / They keep it all hid."19 So do we in the legal academy keep mental disability law "all hid." I hope this essay helps bring this scandal to light. ${ }^{20}$

\section{The Creation of MENTAL Disability LAW}

When I was a law student, I took a course titled "Psychiatry and Law." We used the then-standard book (by Andrew Watson) that sought to explain psychiatry to lawyers. ${ }^{21}$ Persons with mental disabilities-as people-were

17. BoB DYLan, SUbTeRRANEAN Homesick Blues (Sony Music Entertainment Inc. 1967).

18. Jean Tamarin, Bringing It All Back Home, in THE CAMBRIDGE COMPANION TO BOB DYLAN 13I, 133 (Kevin J.H. Dettmar ed., 2009).

19. See DYLAN, supra note 17.

20. "Try to avoid the scandals." See id.

21. See ANDREW S. WATSON, PSYCHIATRY FOR LAWYERS (1968) [hereinafter. WATSON, 1 ed.]. Only twenty-five pages of this 318 page book-the final chapter-dealt with questions of law, and this material focused solely on the perspective of accuracy of diagnosis and the quality of psychiatric testimony. The remainder of the book focused on psychiatric terminology, from a decidedly Freudian perspective. See infra note 22. Subsequent editions, even those published after the first and second wave of major litigation at the U.S. Supreme Court level, see supra text accompanying note 2, devoted no more attention to questions of law. See ANDREW S. WATSON, PSYCHIATRY FOR LAWYERS (revised ed. 2d printing, 1985) (no Supreme Court decision mentioned in the chapter on "Mental Illness and the Law"). Before taking this course, I had taken a course in Psychoanalysis and the Law (taught by Prof. Martin Levine), which was the most 
secondary or even tertiary to the heart and soul of the course; it was about psychiatric nomenclature and terminology. ${ }^{22}$ Even the first casebook that seriously considered the issues that affected such individuals still included the word "psychiatry" in its title. ${ }^{23}$ It was not until Ralph Reisner published the first edition of his casebook in 1985 that this course was unmoored from a strict psychiatry focus. $^{24}$

Interestingly, here, the courts were ahead of the scholars. As I discussed in the introduction, the U.S. Supreme Court has been intensely interested in the constitutional aspects of the civil commitment process since its decisions in Jackson in $1972^{25}$ and $O^{\prime}$ Connor in $1975 .^{26}$ State Supreme Courts $^{27}$ and federal district and appellate courts ${ }^{28}$ contributed a "dizzying proliferation of cases." 29 And all of these cases focused on a question very different than the regulation of professionals. They focused, in Federal District Court Judge Harold Ackerman's unforgettable phrase, “[on] how [plaintiffs] are treated as human beings." I0 I was the lawyer for plaintiffs in that case and have recently written that it "changed my life."31 It also irrevocably changed the way I thought about mental disability law.

profound experience I had had in law school. See Preface to the First Edition in PERLIN, supra note 3 , at ix.

22. WATSON, 1 ed., supra note 21. Chapter titles included "The Lawyer and His Client: The Process of Emotional Involvement"; "The Ego and Its Defenses"; "The Development of Control: The Anal Period," and "The Phallic Period and the Oedipus Complex." Later editions of the book (in 1973 and 1978) followed the same model, and, in spite of the first wave of important Supreme Court and other trial and appellate cases, see supra text accompanying notes 2-3, included no more case law or statutory discussions.

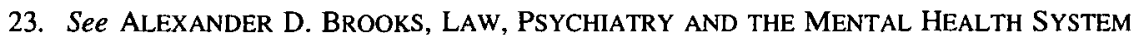
(1974).

24. See RALPH REISNER, LAW AND THE MENTAL HEALTH SySTEM: CiviL AND CRIMINAL ASPECTS (1985).

25. Jackson, 406 U.S. at 736-39.

26. O'Connor, 422 U.S. at 576.

27. Krol, 344 A.2d at 297-98.

28. Wyatt v. Stickney, 325 F. Supp. 781,784 (M.D. Ala. 1971), aff'd in part sub nom. Wyatt v. Aderholt, 503 F.2d 1305 (5th Cir. 1974); Lessard v. Schmidt, 349 F. Supp. 1078, 1084 (E.D. Wis. 1972); see supra note 3.

29. Perlin, supra note 1, at 11. These cases led "to the articulation of a constitutional right to treatment, the more-controversial right to refuse treatment (mostly in cases dealing with the unwanted imposition of psychotropic or antipsychotic medications), and a series of cases sketching out the substantive and procedural constitutional limitations on the involuntary civil commitment power." Id.

30. Falter v. Veterans' Admin., 502 F. Supp. 1178, 1185 (D.N.J. 1980); see Michael L. Perlin \& John Douard, "Equality, I Spoke That Word/As If a Wedding Vow": Mental Disability Law and How We Treat Marginalized Persons, 53 N.Y.L. SCH. L. REV. 9, 10-11 (2008) (discussing the significance of this phrase in the development of mental disability law).

31. Perlin \& Douard, supra note 30 , at 10. 
When I became a full-time law teacher in 1984, I taught a course in "Mental Health Law." 32 Before I joined the faculty, the course had been titled "Legal Regulation of Psychiatry." My decision to change the title was not an effort at political correctness, but an effort to reflect how the questions that students considered in that course-the civil commitment process, the rights of institutionalized persons, deinstitutionalization, and the interplay between mental disability and the criminal trial process ${ }^{33}$-affected hundreds of thousands of people $\mathrm{e}^{34}$ and that the developing law was focused much more on the persons affected than on the issues involving professional regulation.

Interestingly, and most likely not coincidentally, in 1990, the Association of American Law Schools changed the name of the section that had formerly been known as "Law and Psychiatry" to "Law and Mental Disability," to better reflect, in the words of then-section chair Professor Linda Fentiman, "the more diverse interest of its members." 35 In many ways, this was the first academic acknowledgment that "mental disability law" was a true academic discipline.

\section{HOW MANY COURSES?}

As I indicated above, after teaching "Mental Health Law" for three years, it became clear to me that it was impossible to cram all that was needed into a single two-credit course, so I split the criminal law material off to create a new

32. I subsequently began to use the phrase "mental disability law" as recognition that this area of the law governed also persons with intellectual disabilities (then more frequently called "mental retardation").

33. Those issues were spun off into a course of their own about three years later. See infra note 58 and accompanying text.

34. In 1955 , there were 558,239 patients in state and county psychiatric hospitals in the United States. Rachel A. Scherer, Toward a Twenty-First Century Civil Commitment Statute: A Legal, Medical, and Policy Analysis of Preventive Outpatient Treatment, 4 IND. HEALTH L. REV. 361,416 (2007). In 1985, more than 100,000 individuals were so institutionalized at state mental hospitals. See Leona L. Bachrach, Deinstitutionalization: What Do the Numbers Mean?, 37 HoSP. \& COMMUNITY PSYCHIATRY 118, 118 (1986). In 1982, there were 344,000 admissions, readmissions, and returns from leave at those hospitals. Id. Michael L. Perlin, Competency, Deinstitutionalization, and Homelessness: A Story of Marginalization, 28 Hous. L. REV. 63, 82 $\mathrm{n} .115$ (1991). By 1996, the number of patients in state and county psychiatric hospitals had dropped to just 61,722 . Scherer, supra at 16 . There is still much mystery surrounding even the most rudimentary data collection about this population. See NATIONAL Alliance ON MENTAL ILlNESS, GRADiNG THE STATES: A REPORT ON AMERICA's HEALTH CARE SySTEM FOR AdULTS WITH SERIOUS MENTAL ILLNESS 16 (2009), available at http://www.nami.org/gtsTemplate09. $\mathrm{cfm}$ ?Section=Grading_the_States_2009\&Template=/ContentManagement/ContentDisplay.cfm\& ContentID=75459 ("Many states are unable to report even basic information about their mental health services. Many do not know, for example, the total number of inpatient psychiatric beds in their systems.").

35. ASSOCIATION OF AMERICAN LAW SChOOLS: 1990 PROCEEDINGS 363 (1991); email from Tracie Thomas, Senior Meetings Manager, Association of American Law Schools, to Michael L. Perlin (Sept. 3, 2009) (on file with author). 
course called "Criminal Law and Procedure: The Mentally Disabled Defendant." This subject had always been a special interest of mine, ${ }^{36}$ and it seemed to make no sense to squeeze all the relevant material into three or four weeks, especially since the U.S. Supreme Court was becoming more and more interested in the area. ${ }^{37}$ Two years later, the rapid development of therapeutic jurisprudence as a school of thought in mental disability law ${ }^{38}$ led me to create a third mental disability law course on that topic, and two years after that, the expansion of NYLS's workshop program led me to create an experientiallybased course, "Mental Disability Litigation Workshop and Seminar." gave us four courses, the most offered by any law school in the United States. But this was just a harbinger of things to come. As I discuss below, NYLS now offers twelve different courses in mental disability law (to become thirteen in academic year 2010-11). ${ }^{40}$ Often, I am met with incredulous looks ("Why does the law school need so many courses? Can't it all be taught in one

36. Before I became a law professor, I spent three years as a Deputy Public Defender in Trenton, NJ and eight years as Director of the Division of Mental Health Advocacy in the New Jersey Department of the Public Advocate. See Michael L. Perlin, Mental Patient Advocacy by a Public Advocate, 54 PsychiaTRIC Q. 169, 169 (1982); Stanley C. Van Ness \& Michael L. Perlin, Mental Health Advocacy: The New Jersey Experience, in MENTAL HEALTH ADVOCACY: AN EMERGing ForCE In CONSUMERS' Rights 62 (Louis E. Kopolow \& Helene Bloom eds. 1977).

37. See Michael L. Perlin, The Supreme Court, the Mentally Disabled Criminal Defendant, and Symbolic Values: Random Decisions, Hidden Rationales, or Doctrinal Abyss?, 29 ARIz. L. Rev. 1, 1-6 (1987); Michael L. Perlin, The Supreme Court, the Mentally Disabled Criminal Defendant, Psychiatric Testimony in Death Penalty Cases, and the Power of Symbolism: Dulling the Ake in Barefoot's Achilles Heel, 3 N.Y. L. SCH. J. HuMAN RTs. 91, 167-68 (1985).

38. See Therapeutic JuRISPRUDENCE: THE LAW AS a Therapeutic Agent 4 (David B. Wexler ed. 1990); ESSAYS IN THERAPEUTIC JURISPRUDENCE 15 (David B. Wexler \& Bruce J. Winick eds. 1991); LAW IN A THERAPEUTIC KEY: DEVELOPMENTS IN THERAPEUTIC JURISPRUDENCE, at xviii (David B. Wexler \& Bruce J. Winick eds. 1996); THERAPEUTIC JURISPRUDENCE APPLIED: ESSAYS ON MENTAL HEALTH LAW 11 (Bruce J. Winick ed. 1997).

39. In the early 1990s, NYLS created a series of workshop courses in an effort to combine theory and practice in an advanced course experience. This course, open only to students who had completed one of the introductory survey courses, placed students in law offices that did mental disability law work (the "workshop" part) and studied transcripts in individual, obscure cases to analyze the role of the lawyer and the quality of lawyering in such cases. New York Law School Mental Disability Litigation Seminar and Workshop, http://www.nyls.edu/academics/ catalog_and_schedule/alpha_list/mental_disability_litigation_seminar_and_workshop $1 \%$ The transcripts in two of these cases (In re Commitment of E.G., and In re Commitment of M.J.), are reproduced in Michael L. PERLIN, MENTAL Disability LAW: CASES AND MATERIALS 298-324 (2d ed. 2005).

40. It is my belief that only two other schools-the University of New Mexico and the University of Southern California-offer as many as three courses in this area of the law. See Survey, supra note 9. 
course?"). Of course, law school faculty would never think that "all" tax law, real estate law, or securities law could taught in one course. ${ }^{4 I}$

\section{THE ONLINE PROGRAM}

\section{A. The Pedagogy}

I have told in several law review articles (and elsewhere) the story of how the online program in mental disability law was created at NYLS due to the vision of Dean Richard Matasar. ${ }^{42}$ Briefly, it began with one course in 2000 (offered then only as a CLE/CEU course) and has since grown to thirteen courses, an MA in mental disability law studies, and an Advanced Certificate in mental disability law studies. ${ }^{43}$ The pedagogy includes these elements:

- Fourteen hours of video ${ }^{44}$

- Weekly reading assignments

- Detailed web pages, including learning objectives and directed study questions

- On-going, threaded, on-line asynchronous discussion boards;

- A weekly, moderated on-line chat room; and

- Two live day-long seminars, one soon after the course begins, and one at the course's conclusion. ${ }^{45}$

I have written as clearly as I can about my view of this teaching methodology: "I believe that the single most important pedagogic development since I entered law school (nearly forty years ago) has been the creation of online distance learning programs as part of the law school curriculum." 46

41. For a discussion on how this reflects-either consciously or unconsciously-the pervasive power of sanism, see infra Part IV.

42. See, e.g., Michael L. Perlin, "Ain't No Goin' Back": Teaching Mental Disability Law Courses Online, 51 N.Y.L. SCH. L. REV. 991,993 (2006) [hereinafter Teaching Online]; Michael L. Perlin, An Internet-Based Mental Disability Law Program: Implications for Social Change in Nations with Developing Economies, 30 FORDHAM INT'L L.J. 435, 438 n.13 (2007) [hereinafter Social Change]; Michael L. Perlin, A Distance Learning Course on Mental Health Issues in Jails and Prisons, in The Proceedings OF THE 2007 NORTH AMERICAN CoRreCtional \& CRIMINAL JUSTICE PSYCHOLOGY CONFERENCE 125, 126 (Guy Bourgon et al. eds., 2008).

43. See New York Law School, Online Mental Disability Law Program, http://www.nyls.edu/mdl; see also William Wang, The Restructuring of Legal Education Along Functional Lines, 17 J. CONTEMP. LEGAL IsSUES 331, 362-63 (2008).

44. These are mostly "talking heads" and slideshow presentations, but there are also several simulated trials, simulated interviewing, counseling exercises, and roundtable discussions.

45. See Perlin, Teaching Online, supra note 42, at 996.

46. Id. at 992 . For a discussion of the social value of online distance learning programs, see infra note 66 and accompanying text. 
B. The Courses

Our courses include: ${ }^{47}$

- Advocacy Skills in Cases Involving Persons with Mental Disabilities: The Role of Lawyers and Expert Witnesses; ${ }^{48}$

- The Americans with Disabilities Act: Law, Policy and Practice ${ }^{49}$

- Custody Evaluations, Juvenile and Family Law and Persons with Mental Disability;

47. Descriptions of all courses are taken from the NYLS website. See New York Law School, Online Mental Disability Law Program: Course Descriptions, http://www.nyls.edu/ academics/graduate_and_certificate_programs/mental_disability_law_masters/course_description (last visited April 2, 2010). I include them here to give the reader a sense of the richness and scope of the subject matter.

48. Id.

The goal of this course is to teach students the special advocacy skills needed by lawyers and expert witnesses that are essential in cases involving persons with mental disabilities. The course will cover topics including civil commitment standards; outpatient commitment; issues of proof; dealing with expert witnesses; rights to community services; forensic issues; patient advocacy issues; and dealing with stigma/public awareness.

In addition to the lecture-based presentations on streaming video (that are the basis in all of the online mental disability law courses), this course includes two simulated trials, one of an involuntary civil commitment case, and one of an incompetency to stand trial hearing. The lawyers and judges in these simulated trials are the course instructors; the patients are depicted by attorneys whose work focus is mental disability law; the expert witnesses are forensic psychiatrists.

Id.

49. Id.

[The course e]xplores legal, policy, and practical implications of the Americans with Disabilities Act as it applies to people with both physical and mental disabilities (with a significant focus on issues involving mental disability).

The course will cover the wide range of disability-based discrimination that the ADA addresses, including questions of discrimination; access to services; access to the judicial system; institutional rights; and community rights. Students will study the contextualization of the ADA and mental disability law jurisprudence; definitions of 'disability'; issues involving employment discrimination; discrimination in public accommodations and professional licensing; housing discrimination; discrimination in public services; institutional segregation as discrimination; the ADA \& the criminal justice system; and sovereign immunity \& access to courts.

Id.

50. Id.

This course will consider the full range of issues related to custody (including issues specifically related to children with special needs), adoption, marriage dissolution, foster care, domestic abuse and guardianships as they relate to persons with mental disabilities. Students will examine the special issues related to juvenile commitments to psychiatric institutions (and treatment of juveniles in such facilities); competency; as well as other issues related to the criminal trials of juveniles with mental disabilities. This course will 
- Forensic Reports, the Role of Experts, and Forensic Ethics; ${ }^{51}$

- International Human Rights Law and Mental Disability Law;

- Mental Health Issues in Jails and Prisons, ${ }^{53}$

- Mental Disability and Criminal Law; ${ }^{54}$

furthermore focus on the role of problem-solving courts, and the application of international human rights principles to this area of the law.

Id.

51. Course Descriptions, supra note 47.

This course will deal with both the reports that are prepared by forensic experts for use by lawyers (both pre-trial and at trial), and with the ethical issues that are posed when such experts interact with the legal system. The focus will be on the full range of issues involving forensic experts and the mental disability law system: the rights of persons subject to institutionalization and who have been institutionalized, and the role of mental disability in the criminal trial process, in the civil trial process, in the criminal trial process, and in the family law process. Therapeutic jurisprudence implications will be also be explored, as will a consideration of the varying ethical codes that apply to the different mental health professions.

Id.

52. Id.

This course will examine the relationship between constitutional mental disability law and international human rights law, primarily as that relationship deals with questions of legislative drafting, legal representation, institutional treatment, community care, and forensic mental health systems. It will cover a comparison of civil and common law systems, an overview of international human rights law, an overview of regional human rights tribunals, an overview of US constitutional mental disability law, the role of 'sanism' and 'pretextuality' in understanding developments in this area, mental disability law in an international human rights context, comparative mental disability law, the use of institutional psychiatry as a means of suppressing political dissension, the "universal factors" in this area of law, and the globalization of disability law. The focus will be on both American law and on international human rights norms (e.g., the UN Principles for the Protection of Persons with Mental Illness), and the developing body of case law in the Inter-American and European Courts and Commissions on Human Rights.

Id.

53. Id.

This course offers a comprehensive overview of the mental disability law issues in correctional settings (jails \& prisons). Topics include the historical development of the constitutional right to correctional health and mental health care, issues involving staffing, transfer, record keeping, suicide prevention, the significance of professional standards, the relationship between correctional mental health care and community systems of care, monitoring, informed consent, risk assessment, and privatization of services.

Id.

54. Id.

This course will explore in depth the relationship between mental disability and the criminal trial process. Topics to be discussed will include all aspects of the criminal incompetency status (including trial, plea, counsel waiver and other pre-trial, trial and post-trial stages); the insanity defense; institutionalization and release policies that govern the cases of persons found permanently incompetent to stand trial and those found not guilty by reason of insanity; the right of forensic patients to refuse antipsychotic 
- Mental Illness, Dangerousness, the Police Power and Risk Assessment ${ }^{55}$

- Race, Gender, Class, and Mental Disability; ${ }^{56}$

- Sex Offenders; ${ }^{57}$

medications; the role of mental disability evidence in other aspects of criminal trial and pre-trial proceedings (including confessions and privilege against self-incrimination matters); sentencing, the death penalty (including issues involving mitigation, predictions of future dangerousness, executability of persons with mental retardation, and competency to be executed); and questions as to the effectiveness of counsel in cases involving mentally disabled defendants. Class videos will include a simulated trial of a case involving a criminal defendant with a mental disability.

Id.

\section{Id.}

This course will deal with the relationship between mental illness, dangerous behavior and the police power, the ability of mental health professionals to predict dangerousness, and the significance of risk assessment instruments for a variety of decisions to be made in the legal system. Students will discover how these relationships and concepts play out[] in a variety of settings, including involuntary civil commitments, right to refuse treatment, insanity defense acquittee retention hearings, sex offender status hearings, sentencing cases, death penalty 'future dangerousness' inquiries, death penalty mitigation hearings, and Tarasoff (duty to protect) cases in civil law. Id.

\section{Course Descriptions, supra note 47.}

Individuals with mental disabilities have traditionally been and continue to be subjected to rights violations and pervasive discrimination because of their mental disabilities. For individuals who are racial minorities and/or are women, and/or without economic means, and/or not from the dominant culture, the struggles to overcome these rights violations and discrimination are even greater precisely because of their race and/or gender and/or social class and/or culture. The confluence of mental disability, gender, race, culture, and class often result in unique legal issues that have a far reaching impact on virtually every aspect of their lives.

ld.

\section{Id.}

This course will review contemporary public policy regarding sexually coercive behavior. A major focus will be the aggressive legislative approaches to sexual violence developed in the United States over the past 15 years. We will examine and evaluate these controversial legal approaches, as well as alternative approaches to the societal effort to address sexual violence. The course will include an examination of the current state of social science research into sexual violence, including etiology, classification, treatment, supervision, recidivism, and risk assessment. Our examination of legislative approaches to sexual violence will seek an understanding of the operation of these laws, the constitutional litigation challenging them, the legal issues currently in controversy, and an attempt to assess their efficacy as part of a system for addressing sexual violence in society. The course will address issues at a variety of levels of abstraction, examining the morality of the laws, their implications for public policy and the fight against sexual violence, as well as the practical skills and knowledge necessary for lawyers and other professionals to operate effectively.

Id. 
- Survey of Mental Disability Law; ${ }^{58}$

- Therapeutic Jurisprudence; ${ }^{59}$ and

- Trauma and Mental Disability. ${ }^{60}$

\section{Id.}

This course is the gateway to all mental disability law courses as it provides a comprehensive look at many of the issues that will be considered at greater length in the more specialized classes, and provides the basic doctrines fundamental to the understanding of mental disability law. Students will examine the civil and constitutional bases of mental disability law in such areas as civil commitment; institutional rights (with specific focus on the right to refuse treatment); and deinstitutionalization, aftercare, and federal statutory rights (with specific focus on the Americans with Disabilities Act). Students will explore the role of mental disability in the criminal trial process, including criminal incompetencies; insanity defense; sexually violent predator laws; federal sentencing guidelines; and the death penalty. Students will also study the history of mental disability law and why and how it has developed as it has; and most importantly, why judges and fact finders decide mental disability law cases the way they do, to Id. facilitate our predictions of future trends and outcomes.

59. Id.

Students explore the proposition that all aspects of the legal system (and all roles played by judicial actors) have some therapeutic impact on mentally disabled individuals who are litigants or are the subject of litigation. The course focuses on the empirical issues and social assumptions underlying the major mental disability legal doctrines developed in the past three decades in such areas as involuntary civil commitment law, rights of persons institutionalized because of disability, correctional law, the criminal trial process, legal education, and international human rights law.

Id.

60. Id.

The class covers several primary themes of interest to legal practitioners, mental health clinicians, and disability advocates. These include: the treatment of trauma-related disabilities in civil and criminal courts, the role of trauma in the legal treatment of people with mental disabilities, and the relationship between trauma and disability subordination. The course also entails review of the possible policy, legal, and therapeutic points of intervention, geared towards shifting the relationship between law, trauma, and people with mental disabilities. Issues will be examined through a legal, legislative and policy lens.

Some issues explored include the following: how issues involving trauma induced mental disabilities, such as PTSD, among others, are dealt with in both civil and criminal courts; a special focus on children, who experience domestic violence and abuse in foster care or in juvenile detention which results in trauma induced mental disability and how this arises in this context related to eligibility of children in special education under the Individuals with Disabilities Education Act or for school accommodations for these disabilities under Section 504 of the Rehabilitation Act; trauma induced mental disabilities related to veterans who return from the Iraq war with PTDS and end up in the criminal justice system or have civil issues relating to their disability such as employment discrimination, access to mental health treatment and services; issues related to women with trauma induced mental disabilities as a result of rape, abuse, trafficking, war and as refugees and prisoners/inmates both in the civil and criminal context. Furthermore, the 
Depending on demand, there is another array of courses that have been tentatively approved by the faculty. These include Health Care Financing Law, Health Benefits and Entitlements Law, Antitrust Problems in Health Care Law, Mental Health Courts, Complex Mental Disability Litigation, and Bioethics. $^{61}$

\section{The Interdisciplinarity}

I started teaching Mental Health Law in 1985. By 1987, I agreed to accept any and all Forensic Fellows from the NYU Medical School's post-doctoral program as auditors. The next year, I accepted Forensic Fellows from NY Medical College. Over the next few years, I also accepted - on an individualized basis-Ph.D. students and post-doctoral students from Columbia and Fordham's graduate schools of psychology. I was used to teaching nonlawyers from my days in practice; for several years, I worked with my friend and colleague, Dr. Robert Sadoff (a prominent forensic psychiatrist affiliated with the University of Pennsylvania), to train physicians, other mental health professionals, correctional officials, and probation and parole workers in all aspects of mental health law. ${ }^{62}$ Starting in 1975 , I presented papers and participated in workshops regularly at the annual conferences of the American Academy of Psychiatry and Law and at conferences run by other physician and mental health professional groups. So I was always comfortable teaching "mixed" classrooms. I found that having psychiatrists and others in our "bricks and mortar" classes at NYLS inevitably enlivened and enhanced the classroom discourse and gave rise to some of the very best teaching moments of my career.

When we offered the first section of the Survey course online in 2000, most of the students were forensic or administrative psychologists (and in that first year, the course was not offered as a credit-bearing course to NYLS students). Starting in 2002, we began to offer this course to our students, but also sought to add nonmatriculant students as well (these being, at that time, mostly forensic psychologists and psychiatrists whom I had gotten to know through my work and practice in New York and New Jersey). As our program

course will probe unique legal issues presented by stigma and trauma induced disabilities and how applying the concepts of therapeutic jurisprudence can be used to address and hopefully reduce stigma.

Id. This course will be offered for the first time in academic year 2010-11.

61. See Proposal: a Masters Program in MENTAl Disability Law Studies (rev. October 5, 2006) (on file with author).

62. This was in partial fulfillment of an NIMH grant. The first year, we trained this cohort in Philadelphia; the second, in suburban Philadelphia counties; the third, throughout northeast and central Pennsylvania. I discuss my work with Dr. Sadoff in Michael L. Perlin, "May You Stay Forever Young": Robert Sadoff and the History of Mental Health Law, 33 J. AM. ACAD. PSYCHIATRY \& L. 236, 243 (2005). 
has grown in scope and in number of courses, this cadre has increased in number and in breadth. We now have a contract with the Chicago School of Professional Psychology, which sends multiple students each term for both the Jails and Prisons course and the Sex Offenders course. Our non-NYLS students regularly include practicing attorneys, forensic psychologists, forensic psychiatrists, social workers, hearing examiners, court advocates, case workers, and others whose focus is philosophy or ethics. ${ }^{63}$ This heterogeneity of class composition adds so much for all concerned (and, to a person, the law students have been pleased with this array of students with other professional backgrounds).

\section{The Intersectionality and Internationality}

In addition to offering courses at New York Law School, we offer these courses at other domestic law schools and in collaboration with international partners. We offer our Survey course on an ongoing basis domestically at Southern University Law Center, at McGeorge Law School, and at Gonzaga University Law School, and also offer the $A D A$ course at Southern University Law Center and at McGeorge Law School. ${ }^{64}$

We have also offered sections of our Survey courses in Japan (in conjunction with the Tokyo Advocacy Law Office) and in Nicaragua (in conjunction with Universidad Americana Managua), and the $A D A$ course in Japan (also with the Tokyo Advocacy Law Office). ${ }^{65}$ We are planning on offering a section of the Advocacy Skills class in the 2010-11 academic year in conjunction with Kanagawa University (in Yokahama, Japan), and have signed memoranda of understanding to offer sections of our International Human Rights course at a law school in Shanghai, and sections of our Jails and Prisons and International Human Rights courses at a law school in Uganda (the latter both contingent on obtaining third-party funding).

I have said this about the program in Nicaragua:

The Internet has the capacity to transform and invigorate legal education through the use of distance learning methodologies. The first Internet-based mental disability law course, offered domestically in 2000 , has now expanded

63. One of the forensic psychologists and one of the forensic psychiatrists are Australian practitioners.

64. Perlin, Teaching Online, supra note 42, at 999 . We also offered a section of the Survey course at Oklahoma City University School of Law in the Spring 2006 term. Students from Concord Law School also regularly take our online courses as well. Id. at 997 n.49. In addition, students from other law schools regularly take these courses as "visiting students." Id.

65. Id. at 999. I discuss the Nicaragua program extensively in Perlin, Social Change, supra note 42, at 451-53, nn.74-78. In Japan, the courses were also offered in partnership with the Association for Better Mental Health and with Zenkanren. Id. at 446 n.49. In Nicaragua, the course was also offered in partnership with the Nicaraguan Association for Community Integration and with Inclusion Interamericana. Id. 
to include international sections, such as the one in Nicaragua in the Fall 2002 semester. Building on the course's pedagogy, the instructors continued to work with local activists in Nicaragua after the course formally concluded. The instructors are also actively seeking to offer the course both to other important parties in Nicaragua (the judiciary) and to groups in other Central American nations. It is hoped that this model will be successfully replicated in these nations and elsewhere. ${ }^{66}$

I believe that the online format-allowing us to create these partnerships in other parts of the world-has been a major factor in what I perceive (and what others perceive) ${ }^{67}$ as the success of our program. It also, as I will discuss next, allows us to teach the core concepts that continue to dominate the practice of mental disability law "on the ground" nearly four decades after the Supreme Court's decision in the Jackson case.

\section{The JURISPRUDENCE OF MENTAL DisABILITY LAW}

What matters most in the teaching of mental disability law is the recognition that to simply teach a series of easy-to-outline holdings as if this were just another boutique class in the curriculum is nothing less than academic malpractice. I believe that, unless students studying mental disability law understand the concepts of (and the poisonous residue of) sanism and pretextuality, the pitfalls of false "ordinary common sense" (OCS) and heuristic reasoning, ${ }^{68}$ and the significance of therapeutic jurisprudence, teaching this course may well be a vacuous and meaningless exercise. It is also necessary to teach these concepts so students can grasp the enormous cognitive dissonance between the expansive due process holdings of many of the important U.S. Supreme Court and appellate decisions in this area, and the crabbed decision-making undertaken in trial courts (and in relatively unknown reported cases) that is so common to this area of law. ${ }^{69}$

What do I mean by these terms? Earlier in this Article, I discussed the pernicious impact of sanism. ${ }^{70}$ Sanism infects both our jurisprudence and our lawyering practices. As I have previously stated it "is largely invisible and largely socially acceptable. It is based predominantly upon stereotype, myth, superstition, and deindividualization, and is sustained and perpetuated by our

66. Perlin, Social Change, supra note 42 , at 454.

67. See Wang, supra note 43 , at $361-63$ (noting throughout the article the advantages of technology and distance learning and citing the NYLS mental disability law courses as an example).

68. See infra text accompanying notes 75-78.

69. See Michael L. Perlin, A Law of Healing, 68 U. CIN. L. REV. 407, 425-26 (2000) ("[T]he overwhelming number of cases involving mental disability law issues are 'litigated' in pitch darkness. Involuntary civil commitment cases are routinely disposed of in minutes behind closed courtroom doors.").

70. See supra text accompanying notes 10-11. 
use of alleged $\mathrm{OCS}^{71}$ and heuristic reasoning ${ }^{72}$ in an unconscious response to events both in everyday life and in the legal process.,"73 But there are other concepts that must be made clear to students if the teaching of mental disability law is to have any authentic meaning.

Pretextuality refers to the ways in which courts:

[A]ccept (either implicitly or explicitly) testimonial dishonesty and engage similarly in dishonest (and frequently meretricious) decisionmaking, specifically where witnesses, especially expert witnesses, show a high propensity to purposely distort their testimony in order to achieve desired ends. This pretextuality is poisonous; it infects all participants in the judicial system, breeds cynicism and disrespect for the law, demeans participants, and reinforces shoddy lawyering, blasé judging, and, at times, perjurious and/or corrupt testifying." 74

Consider further the meretricious role of OCS. Underlying much pretextuality is society's use of OCS, a "powerful unconscious animator of legal decision making."75 "[W]here defendants do not conform to "popular images of craziness,' the notion of handicapping mental disability is flatly and unthinkingly rejected."76 In arguing why it is essential to understand OCS if one is to understand why insanity defense attitudes have developed as they have, I have said:

Not only is it 'prereflexive' and 'self-evident,' it is susceptible to precisely the type of idiosyncratic, reactive decisionmaking that has traditionally typified insanity defense legislation and litigation. It also ignores our rich, cultural, heterogenic fabric that makes futile any attempt to establish a unitary level of OCS to govern decisionmaking in an area where we have traditionally been willing to base substantive criminal law doctrine on medieval conceptions of sin, redemption, and religiosity. ${ }^{77}$

71. See infra text accompanying notes $75-77$.

72. See infra text accompanying notes 78-79.

73. Perlin, supra note 1 , at 4-5; see also MiCHAEL L. PERLIN, THE HiddEN PREJUdicE: MENTAL DISABILITY ON TRIAL, at xviii-xix (2000).

74. Michael L. Perlin, "She Breaks Just Like a Little Girl": Neonaticide, the Insanity Defense, and the Irrelevance of "Ordinary Common Sense," 10 WM. \& MARY J. WOMEN \& L. 1, 25 (2003) (quoting Perlin, supra note 1, at 4-5).

75. Michael L. Perlin, Psychodynamics and the Insanity Defense: "Ordinary Common Sense" and Heuristic Reasoning, 69 NEB. L. REV. 3, 22-23 (1990).

76. Id. at 24 (quoting Harold Lasswell, Foreward to RICHARD ARENS, THE INSANITY DEFENSE, at xi (1974)).

77. Id. at 29. 
Heuristics are "simplifying cognitive devices that frequently lead to ... systematically erroneous decisions through ignoring or misusing rationally useful information." ${ }^{78}$ This further contaminates the legal process:

[T] estimony [in mental disability law cases] is further warped by a heuristic bias. Expert witnesses-like the rest of us-succumb to the seductive allure of simplifying cognitive devices in their thinking and employ such heuristic gambits as the vividness effect or attribution theory in their testimony. This testimony is then weighed and evaluated by frequently sanist fact-finders. Judges and jurors, both consciously and unconsciously, often rely on reductionist, prejudice-driven stereotypes in their decision-making, thus subordinating statutory and case law standards as well as the legitimate interests of the mentally disabled persons who are the subject of the litigation. Judges' predispositions to employ the same sorts of heuristics as do expert witnesses further contaminate the process. ${ }^{79}$

Finally, it is essential that students understand the significance of therapeutic jurisprudence (TJ).

TJ presents a new model by which we can assess the ultimate impact of case law and legislation that affects mentally disabled individuals; study the role of the law as a therapeutic agent; recognize that substantive rules, legal procedures, and lawyers' roles may have either therapeutic or anti-therapeutic consequences; and question whether such rules, procedures, and roles can or should be reshaped so as to enhance their therapeutic potential, while not subordinating due process principles. ${ }^{80}$

Judge Ackerman's insight, to which I referred earlier-that "the Falter case was, basically, about whether the plaintiffs, institutionalized because of their mental disability, were treated 'as human beings'"-is as concise and perfect an expression of $\mathrm{TJ}$ as exists in the legal canon. ${ }^{81}$

The law can (and must) use TJ as a mechanism "to expose pretextuality and strip bare the law's sanist facade," 82 and thus become a powerful tool to serve as "a means of attacking and uprooting 'the we/they distinction that has traditionally plagued and stigmatized the mentally disabled." $" 83$ It is an approach that professors-both as classroom teachers and scholars-must always keep in mind.

78. Michael L. Perlin, Fatal Assumption: A Critical Evaluation of the Role of Counsel in Mental Disability Cases, 16 LAW \& HuM. BEHAV. 39, 57 n.115 (1992).

79. Perlin, supra note 15 , at $602-03$.

80. Perlin \& Douard, supra note 30 , at 12.

81. Id.

82. Michael L. Perlin, "Things Have Changed": Looking at Non-institutional Mental Disability Law Through the Sanism Filter, 46 N.Y.L. SCH. L. REV. 535, 544 (2003).

83. PERLIN, supra note 73, at 301 (quoting David B. Wexler, New Directions in Therapeutic Jurisprudence: Breaking the Bounds of Mental Health Law Scholarship, 10 N.Y.L. SCH. J. HUM. RTS. 759, 776 (1993)). 


\section{CONCLUSION}

Mental disability law has been ghettoized in good part because of sociallyacceptable, unthinking (perhaps, at times, unconscious) sanism. This sanism renders invisible both its subject matter and the individuals who are the subject of its caselaw. ${ }^{84}$ Because of this ghettoization, many law schools offer no course in this subject matter, or offer one sporadically by an occasional adjunct. As a result, our biases and prejudices about persons with mental disabilities (and those so perceived) remain hidden in the academy. ${ }^{85}$

NYLS created its Online Mental Disability Law program, in significant part, because of this gap in legal education. Our robust curriculum-including thirteen courses, an Advanced Certificate and a Masters degree-and our global reach were designed to help ameliorate this situation.

But it is not enough to simply offer lots of courses in lots of places. To teach mental disability law meaningfully, it is necessary to teach about the core characteristics that contaminate it (sanism and pretextuality), to teach about the cognitive approaches that distort it (false OCS and cognitive-simplifying heuristics), and to teach the school of jurisprudence that can optimally redeem it (TJ). If we do this, we will no longer, in Dylan's words, "keep it all hid," and mental disability law will finally take its rightful place in the civil rights curricula at all law schools.

84. Unless, of course, the case involves the inexplicably violent act of a "deranged man" or a "raving maniac," both descriptions used about the defendant Colin Ferguson by his own lawyers. Michael L. Perlin, "Dignity Was the First to Leave": Godinez v. Moran, Colin Ferguson, and the Trial of Mentally Disabled Criminal Defendants, 14 BEHAV. SCI. \& L. 61, 79 (1996). At that moment, the vividness heuristic sets in, and that case is seen as typical of all cases involving individuals with mental disabilities, see, e.g., Perlin, supra note 69, at 424 (discussing the cases of John Hinckley, Ferguson, John DuPont, and Ted Kaczynski).

85. See PERLIN, supra note 73, at 309-10 (discussing the invisible and hidden prejudice in mental disability law that has corrupted the legal system and caused those with mental disabilities to suffer). 